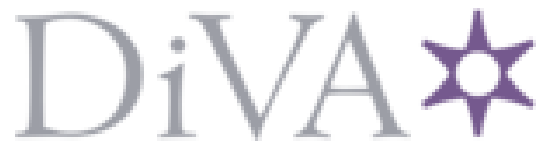

http://www.diva-portal.org

Preprint

This is the submitted version of a paper published in Journal of Political Power.

Citation for the original published paper (version of record):

Wiksell, K. (2017)

Campaigning for cooperatives as resistance to neoliberal capitalism.

Journal of Political Power, 10(2): 236-254

https://doi.org/10.1080/2158379X.2017.1335837

Access to the published version may require subscription.

N.B. When citing this work, cite the original published paper.

Permanent link to this version:

http://urn.kb.se/resolve?urn=urn:nbn:se:kau:diva-62562 


\title{
Campaigning for cooperatives as resistance to neoliberal capitalism
}

\author{
Author: Kristin Wiksell, Department of Social and Psychological Studies, Karlstad \\ University, Sweden. Correspondence: kristin.wiksell@kau.se
}

The Version of Record of this manuscript has been published and is available in Journal of Political Power, 09 June 2017, Volume 10, Issue 2: Resistance and Emotions. www.tandfonline.com/doi/full/10.1080/2158379X.2017.1335837.

\begin{abstract}
This article investigates the eventual performance of critical resistance to neoliberal capitalism in the discourse of a marketing campaign that promotes the organisational form of cooperatives. Through discourse analysis, this article shows that the performed resistance activity in the campaign discourse is non-critical resistance since the dominant discourse of neoliberal capitalism is reproduced. The analysis displays that affective and economic articulations are intertwined in resistance through the discursive promotion of cooperation. The article contributes to understandings of cooperation as potential resistance to neoliberal capitalism, and highlights the risk of resistance simultaneously reproducing the power of dominant discourses.
\end{abstract}

Keywords: cooperatives; critical resistance; affect; neoliberal capitalism; discourse

\section{Introduction}

Capitalism with a conscience.

(Cooperatives for a better world 2016) $^{\mathrm{i}}$

This article investigates the eventual performance of critical resistance to neoliberal capitalism in the discourse of a marketing campaign that promotes the organisational form of cooperatives (co-ops). The analysis will show that affective and economic articulations are intertwined in the discursive promotion of cooperation as a means to resist neoliberal capitalism by creating an affective 'we' and constructing subjects differently. The overarching risk of performing resistance that simultaneously reproduces the power of dominant discourses is investigated through the theoretical concept of critical resistance (Hoy 2004). In doing this, the article contributes to research on resistance (cf Bayat 2000, Lilja and Vinthagen 2014, Odysseous, Death and Malmvig 2016, Scott 1985), and fills a gap in the understandings of how a discursive promotion of cooperation can entail resistance to the dominance of neoliberal capitalist discourse. 
The capitalist goal of profit accumulation has persisted as a dominating principle in the global economy in spite of the critique directed against it over the decades (Boltanski and Chiapello 1999/2007). Key characteristics of modern capitalism such as rationality, capital accounting, freedom of the market, wage-labour, competition, and commodification (Marx 1867/2013, Weber 1927/2007, Paulsen 2010), have become intertwined with a globalised neoliberalism that constitutes subjects as free, autonomous and self-interested Homo Economicus - asking what's in it for me? - through discourses of markets, entrepreneurship, rationality and self-confidence (Brown 2015, Foucault 2008, Hamann 2009, Harvey 2005, Peters 2016, Springer 2016b, Turken 2016). The idea of neoliberalism, 'as the latest incarnation of capitalism, [...] is made flesh through the very power that we assign it through our discursive participation in its routines and rituals, and importantly, through the performances we enact' (Springer 2016b, p. 1). From a Foucauldian perspective on discourse (for example 1982, 2008), further developed by Butler (1993), neoliberal capitalism can be understood as a performatively discursive, materialising process of 'top-down and bottom-up (re)production through continually (re)articulated citational chains' (Springer 2010, p. 931). Different implementations of neoliberalisation is being performed through human activity (Springer 2016b), which means that there are possibilities to perform differently and challenge the dominance of neoliberal capitalism.

Boltanski and Chiapello (1999/2007) argue that for capitalism to be reproduced, it needs to be morally justified in a way that motivates people's engagement in capitalist practices. One example is how the semantic construction of social entrepreneurship 'neutralize the self-seeking aspects of entrepreneurialism' (Holborow 2015, p. 79) and pre-empts the critique that business is only about greed. Reber (2012), following Illouz (2007), points out that affective dimensions such as empathy and care for others legitimise capitalism - capitalism is justified as a homeostatic system, that when in balance, is most beneficial for all. The entanglement of economic reasons and affect in the discourse of neoliberal capitalism denotes that resistance against its dominance should take both aspects into account in order to entail effective emancipation. However, the domination of neoliberal capitalism has constituted certain challenges regarding the prospect of resistance (Hamann 2009). Since freedom and autonomy are part of a neoliberal discourse, subjects are, in a way, already produced as free to act, which implies that no particular freedom constraints motivate resistance. This sought freedom could therefore be the freedom that has already been produced by neoliberalism (Hoy 2004), which means that there is a continuous risk that resistance activities might be co-opted by the power of domination so that it supports rather than stifles that which is being resisted (Foucault 1977). 
Accordingly, for the cooperative movement to perform effective resistance to neoliberal capitalism, it has to resist rather than reinforce the productive power of the neoliberal, capitalist discourse itself, or in other words, avoid to performatively reiterate it (Butler 1993). The present understanding of resistance that is not co-opted by oppressive forces is drawn from the concept of critical resistance, defined by Hoy (2004), as emancipatory resistance to domination (cf Haugaard 2012).

The organisational form of co-ops has the potential to resist the dominance of neoliberal capitalism since the cooperative ideals of 'human solidarity, economic democracy and collective endeavour [...] challenge neoliberalism directly' (Satgar 2007, p. 73). Co-ops are employee-governed, member-owned organisations that emphasise social values and member benefits rather than profit maximisation. Worker co-ops include shared ownership and control where labour rents capital rather than the other way around, and the decision-making principle is often 'one member, one vote' (Spear 2004). General values of self-help, self-responsibility, democracy, equality, equity, and solidarity guide co-ops around the globe, which were adopted in 1995 by the International Co-operative Alliance (ICA 2016c), originated from the first modern co-op in Rochdale, England in 1844. Furthermore, ICA (2016c) outlines seven organisational principles that should guide co-ops, such as voluntary and open membership, cooperation among co-ops, and concern for community. These values and principles come from a social rather than economic-rational sphere, compared with neoliberal self-interest and the capitalist goal of profit accumulation, thus offering a potential to resist neoliberal capitalist discourse through the promotion of cooperation. In Springer's words, 'our community, our cooperation, and our care for one another are all loathsome to neoliberalism' (2016a, p. 289). However, the introductory quote 'Capitalism with a conscience', from a marketing campaign aimed at the promotion of co-ops, indicates that the campaign promotes a form of social change that transforms rather than obstructs neoliberal capitalism.

This article aims to explore the eventual performance of critical resistance to the dominant discourse of neoliberal capitalism in the discursive promotion of cooperation. Specifically, the article investigates how the cooperative alternative is being constructed through discursive articulations of affect and economic-rational reasoning in relation to neoliberal capitalist discourse. Through discourse analysis of the marketing campaign 'Building a better world now', which was initiated in 2015 by ICA (2016a) to promote the cooperative identity, this article shows that the performed resistance activity in the marketing campaign should be understood as non-critical resistance since the dominant discourse of neoliberal capitalism is being reproduced throughout the campaign. The article contributes to research on cooperation 
as resistance, by showing how cooperation is constructed and promoted through discursive articulations of affect and economic reasons that challenge and reproduce neoliberal capitalist discourses. By this, the article emphasises the importance of studying the critical aspects of resistance and including affect in the analysis of discursive resistance to neoliberal capitalism.

\section{Materials and methods}

The present study consists of a discourse analysis of the construction of co-ops in relation to neoliberal capitalism in the global marketing campaign 'Building a better world now', which was initiated on 11 of November 2015 by ICA (2016a). ICA launched the campaign with the explicit aim to promote the cooperative identity and increase the global influence of the cooperative sector. The campaign, which is linked to ICAs (2016b) main website, entails marketing material published online on the campaign's internet website (buildingabetterworldnow.coop (ICA 2016a), presently cooperativesforabetterworld.coop (Cooperatives for a better world 2017)). The campaign, initially piloted in four countries across the globe, is intended to be customisable - engaged co-operators can help spread the message in their communities - and targets people with or without previous engagement in co-ops. The analysed material was collected in the summer of 2016 and consists of publicly available PowerPoint presentations. ${ }^{\text {ii }}$ The first (1), most extensive presentation details the motivation plan for the campaign, intended to promote engagement in the campaign. The second (2) presentation focuses on change through the outlining of an 'action plan' for spreading the cooperative movement. The third (3) presentation consists of just one vertical lengthy slide that describes the plan and possible impact of the enhancement of increased scope of the campaign. The fourth (4) presentation concerns 'the cooperative identity' and entails statements about who (we as) co-ops are, collectively and uniquely. All presentations have a uniform graphic design and are mostly text-based. Some pictures are included, for example the showing of a clock, as are a few authentic photographs: one example depicts hands holding pencils around a table, but none include faces.

The methodology, inspired by the Discourse Theory (DT) of Laclau and Mouffe (2008), is based on the assumption that the radical contingency of discourse makes attempts to discursively fix political meaning. Dominant discourses of seemingly fixed structures that exclude other meanings can be challenged (Torfing 1999). The analysed marketing campaign is thus understood as a social arena for possible critical resistance to the dominance of neoliberal capitalism through attempts to shape meaning differently. The present study follows the interpretation of DT's practical applicability by Winther Jørgensen and Phillips (2000), 
specifically, on how discursive structures are formed through meaning-shaping articulations that relate signs to each other. The analysis consists of the structuring and deconstruction of the different logic of the collected material through the search for the operational concepts signs and nodal points, and how they are situated in relation to each other. Signs are the building parts of the discourse, the dot-points in the web of meaningful differences that constitute a discursive structure. A sign is essentially without content but creates meaning in an articulation when it is placed in a structure of similarity and difference. Signs can entail certain functions in different discursive formations, nodal points are one example. Nodal points are privileged signs that function as a kind of centre of a discourse that other signs then receive meaning in relation to these. The establishment of nodal points is the result of articulatory practices that shape meaning (Torfing 1999, Winther Jørgensen and Phillips 2000). In practice, the discourse analysis was conducted by coding central recurring signs and then investigating how those privileged signs are combined with other signs that give them meaning. These first steps led to the reconstruction of the relatedness between privileged signs and nodal points in an attempt to recreate and analyse the meaning-shaping articulations of the text. The focus is on whether and how co-ops are being articulated - particularly through articulations of affect and economicrational reason, in a way that challenge or reproduce neoliberal capitalist discourse in the search for possible critical resistance within the campaign discourse.

\section{Previous research on cooperatives as resistance}

Research on co-ops has not focused on resistance to any large extent, and research on resistance has scarcely dealt with the empirical case of co-ops, but there are some exceptions. Satgar (2007) writes that co-ops stand apart from the relations of production that push capitalism. By representing an alternative to individual gain and primitive accumulation affiliated with the neoliberal capitalism, the cooperative ideals of 'human solidarity, economic democracy and collective endeavour [...] challenge neoliberalism directly' (Satgar 2007, p. 73). Puusa, Mönkkönen and Varis (2013) also indicate that the cooperative ideals offer resistance, based on a study of economics students' descriptive account of what co-ops are. They show that coops are largely constructed through critical comparison with other types of businesses, by emphasising social rather than economic values, but reflect a dual nature. Co-ops should still be profitable in order to last, and the humanistic, cooperative values might be undermined if profit and growth becomes increasingly important (Puusa et al. 2013). Larger co-ops risk becoming similar to hierarchically governed organisations (Spear 2004). Even if cooperative 
ideals contrast with neoliberal capitalism, this stresses that co-ops do not necessarily entail resistance to neoliberal capitalism in practice.

Cooperation as resistance to neoliberal capitalism can be understood through the concept of 'self-governmental resistance' (Pahnke 2015), referring to the oppositional performance of social movements as institutionalisation of resistance by building a new order. Pahnke (2015) shows how self-governing agricultural production in the form of co-ops is a productive kind of resistance that takes control of policy implementation and design, challenging both state power and neoliberal discourse. However, such institutionalisation creates rules and procedures that both enable and constrain the resistance activity into a certain structure with less flexibility to counter different attempts of dominance. Self-governance also entails entrepreneurship, included in neoliberal discourse (Holborow 2015, Turken 2016), which indicates that resistance to neoliberal capitalism through cooperation is feeble in some areas but might reproduce it in others.

Governmental regulations and policies as well as neoliberal capitalist discourse can entail aggravating circumstances for co-ops regarding both organisation principles and how subjects act and think (Evans 2007). Satgar writes that there are neoliberal attempts to restrain the resistance potential of co-ops by 'appropriating cooperatives into the globally competitive market, commodifying their ownership structure, reducing the developmental role for strategic state support and introducing typical managerial prerogatives', which 'closes off the possibilities for an alternative logic of accumulation based on human needs' (2007, p. 70). Hierarchical ideals in the surrounding society can also be challenging for democracy in co-ops - lack of knowledge about how to practise democracy may bring forth hierarchies within coops, since members might be more familiar with such order-structures (Varman and Chakrabarti 2004). Varman and Chakrabarti (2004) suggest education in democracy within co-ops in order to enhance members' 'democratic consciousness', which is arguably an attempt to resist the productive power of neoliberal discourse through an alternative way of shaping cooperative individuals. The official adoption of cooperative values by ICA (2016c) represents another way in which the movement responds to the risk of being co-opted by neoliberal capitalism, and Satgar (2007) suggests the creation of a strong regional, national and global alliance between the cooperative and labour movements that demands exception from the implementation of capitalist principles. However, other aspects of neoliberal capitalism might simultaneously be reproduced. The cooperative movement thus faces a challenge to advance from the shallow protection of co-ops' ideology against global neoliberalisation into a powerful counterhegemonic struggle that is not merely defensive (Evans 2007). 
The feebleness of co-ops as resistance is emphasised by Whyman (2012) who shows a historical, close association between cooperation and mainstream economics, despite the widespread understanding that neoclassical economists ignore co-ops in economic theory (Whyman 2012). That co-ops are not something completely different but instead included in mainstream economic theory might be an argument against the resistance potential of cooperation. White and Williams (2012) touch upon this last notion in arguing that noncapitalist practices such as cooperation and reciprocity are in fact embedded confidently in the present, but to focus on and construct cooperation as a presently occurring and viable alternative can be a way to perform resistance in itself, that is, by discursively reiterate articulations of desired futures instead of reproducing the idea of the undesired neoliberal capitalism (Butler 1993, Springer 2016b). Similarly, by performing differently from the reiterated values of neoliberal capitalism in everyday life as a form of 'constructive resistance' (Sørensen 2016), neoliberal capitalism can be challenged without overt protest (Springer 2016a). The construction of co-ops as such everyday resistance can be described through the notion of anarchy, understood as mutual aid and cooperation through voluntary association (Springer 2016a). Anarchy offers a way to oppose neoliberal capitalism in practice by performing joint, embodied community control without hierarchical authority (Rothschild and Whitt 1986, Springer 2016a, White and Williams 2016). The potential to perform resistance against neoliberal capitalism through a 'prefigurative politics' of anarchist cooperation is strongly emphasised by Springer, in a paper with the significant title 'Fuck neoliberalism':

\footnotetext{
We can start living into other possible worlds through a renewed commitment to the practices of mutual aid, fellowship, reciprocity, and non-hierarchical forms of organization that reconvene democracy in its etymological sense of power to the people (Springer 2016a, p. 289, emphasis in original).
}

Previous research on co-ops and resistance brings forth the conclusion that the cooperative movement can offer resistance against neoliberal capitalism in some respects, for example through the cooperative ideals (Satgar 2007) and anarchist mutual aid (Springer 2016a), but faces challenges in performing resistance that is critical enough to escape co-optation by neoliberal capitalism. Research on such critical resistance in relation to co-ops is required, as well as research that take a discursive-affective approach to the promotion of cooperation as potential resistance to neoliberal capitalism, which the present discourse analysis contributes with 


\section{Critical resistance}

Resistance has been conceptualised in different ways, but there is agreement that resistance refers to an action that relies on some kind of constraint and a possibility of opposing this 'something else' (Hollander and Einwohner 2004). In this article, the relation between constrain and opposition is understood through the concept of performativity, developed by Butler (1988, 1993). Discursive regimes and material structures have history which function as 'constitutive constraint', by both enabling and impeding the becoming of subjects, and those subjects' performances. Although such constraint 'does not foreclose the possibility of agency, it does locate agency as a reiterative or rearticulatory practice, immanent to power' (Butler 1993, p. 15), with the consequence that historical and material structures are easily reproduced. According to this view, opposition can be described as a shift in the reiteration of norms that breaks away from the normative constraints of discourse and materiality, regardless of whether the 'shift' is intended or not. Resistance can thus be discursively and bodily performed by 'acting differently' (Butler 1988, 1993, 2015, Glass and Rose-Redwood 2014, Scott 1985). The potential opposition to neoliberal capitalism analysed in this article is the discursive articulations of the marketing campaign 'Building a better world now' (ICA 2016a). In order to investigate if resistance that escapes reiteration is being performed through the campaign, I turn to the notion of critical resistance defined by Hoy (2004), in particular his readings of Foucault on power and resistance.

According to Foucault, power is not only repressive domination in a top-bottom relationship, but power 'produces things, it induces pleasure, forms of knowledge, produces discourse' (1980, p. 119). Power does not belong to individual subjects, rather discourse has the power to produce subjects and the appropriate actions for certain subject positions. A central part of how power functions is the ability to make itself true through normalisation processes (Foucault 1977, p. 183). Subjects' disciplinary conformity to a norm incorporates the disciplinary power in subjects' self-control, neutralises discourses, and hides the workings of power. Power functions more effectively the more normalised it is - subjects might not identify the possibility to resist the prevailing order if power is hidden. What seems to be resistance might strengthen rather than subvert domination by hiding its spreading normalisation, which means that resistance is co-opted by the dominating power. Resistance in such cases since does not entail an effective threat. This is where critical resistance enters the picture (Hoy 2004, p. 83). By adding 'critical' to resistance, Hoy means to distinguish it from the type of resistance performed by domination in order to resist emancipatory efforts. Critical resistance is thus defined as emancipatory resistance to domination (Hoy 2004, p. 2). Reactionary resistance 
performed without critique may lack the emancipatory potential of social change and maintain the status quo, since 'utopian imaginings of freedom may not be aware of the extent to which they presuppose the patterns of oppression that they are resisting' (2004, p. 3). Resistance relates to social constraints understood in the structure that produces the constraints, which means that resistance is meaningful only where these constraints are practised and may run the risk of preserving them. Hoy draws upon Nietzsche (1959 cited Hoy 2004, p. 1) who argues that it is constraints of freedom in a social structure that drive the motivation for resistance, but the conscious understanding of freedom might conceal deeper motivations, such as a self-denial of not being free or powerful enough to create own values. This is why neoliberal discourse, in producing subjects as free, autonomous individuals, is especially challenging for the potential of critical resistance - the sought freedom might be the type of freedom that has already been produced by neoliberalism. For resistance to be critical with regard to this risk, it should take the full contingency of social reality into account. No truth is true forever and neither should resistance insist on it being so - that might reproduce prevailing power relations.

Critical resistance with the potential to effectively change the prevailing order questions both domination and the oppressed subject positions. One way to perform critical resistance, according to Hoy's (2004, p. 84) interpretation of Foucault (1997), is to co-opt the domination's own strategies of co-optation; i.e., to use the power's own mechanisms in order to undermine and subvert domination. For example, if science and scientific arguments are used by domination to resist emancipatory effort, critical resistance can be performed by doing the same but differently, and produce scientific results that strengthen its own case. 'Reverse discourse' is another example of such overt resistance, i.e. to use the dominating discourse in a new context and ascribing new meaning to it (Foucault 1988 cited in Hoy 2004, p. 86). The process of desubjectification or desubjugation is also a way to perform critical resistance, related to freedom and the possibility to act differently. Since the power of discourses produces subjects and fixes their positions, desubjectification refers to the questioning of subjects' own understanding of themselves. Desubjectification is the resistance of the discursive production of who people are, of their constructed social identities (Hoy 2004, p. 87).

In the case of the dominance of neoliberal capitalism, critical resistance can be to avoid reproducing discourses of entrepreneurship and rationality as well as the construction of subjects as calculating, self-interested Homo Economicus. Cohen (2004) uses the concept 'politics of deviance' to refer to a way of life that cannot be explained, understood, or valued through the dominating discourse, unable to receive accountability within the logic of, for example, neoliberal discourse. To avoid being explicable according to the values of the 
dominant discourse is thus a form of critical resistance (Cacho 2012, Hoy 2004). In conclusion, critical resistance concerns emancipatory resistance to domination that resists being co-opted by the power of domination and resists the power's productive force of subjectification, without reproducing the dominant discourses of power. The significance of analysing resistance activities from a perspective of critical resistance is given by the overarching risk that resistance maintains the status quo of the social context in which it is being performed. The critical resistance approach to the analysis of the campaign promoting cooperation is complemented with an acknowledgement of the intertwinement of reason and affect in justificatory discourses - it holds for neoliberal capitalism, and is therefore important to take into account when analysing resistance to the same.

\section{Discursive articulations of affect}

Boltanski and Chiapello (1999/2007) argue that capitalism needs to be morally justified in order to be reproduced by acting subjects. Emotional justifications of neoliberal capitalism have been brought to light through the 'affective turn', which is increasingly emphasised in research in different areas (Clough and Halley 2007, McElhinny 2010, Sointu 2016). Reber (2012), following the works of Illouz (2007) arrives at an explanation of affect as the free-market episteme that increasingly overshadows rationality as justificatory logic in present globalised capitalism. Although reason has been articulated as the dominant organisational principle of capitalism, exemplified by the strict calculations of Fordism and Taylorism, the selflegitimising discourse of capitalism was originally 'based on the moral balance of homeostatic health and well-being' (Reber 2012, p. 77). Moral sentiments of empathy and sympathy are included in the notion of capitalism as a homeostatic flow that is most beneficial for all. Reber emphasises that affect-as-episteme can be understood as 'a tool of social domination as well as a tool of liberational contestation' (2012, p. 92), pointing to several cases where capitalism has been opposed through a 'protest discourse [that] features empathy as a guiding logic of the action and objectives' (2012, p. 90). The entanglement of reason and affect in the discourse of capitalism point to the importance of studying critical resistance against neoliberal capitalism by taking both aspects into account.

The discursive aspects of affect induce a perspective on feelings as textual and social affect, existing in the encounters between subjects and in relation to signs (Ahmed 2004b, 2014, McElhinny 2010, Richard and Rudnyckyj 2009). A view on affect as movement between subjects and signs can contribute to an understanding of how the discursive articulations in the present campaign discourse might affectively appeal to the connecting of people both to each 
other and to certain textual representations. Ahmed (2004a) outlines a view where 'movement between signs converts into affect' (Ahmed 2004a, p. 120). Affect circulates between bodies and signs through relationships of difference and adherence, which either bind or separate subjects and objects depending on how words are articulated. 'Emotions' in such affective economies accumulates over time, and 'work by sticking figures together (adherence), a sticking that creates the very effect of a collective' (Ahmed 2004a, p. 119). Affect surfaces specific individuals by moving between them and forming boundaries that shape collectives and exclude others by, for example, continuously constructing a discursive 'we' that appeals to certain subjects (Ahmed 2004b). Repeated formations of solidarity and care in descriptions of co-ops can accumulate love between appealed subjects and the sign 'cooperative', and repeated formations of a collective 'we' can entail the accumulation of affect between people of the cooperative movement. This collective is simultaneously differentiated from uninvolved outsiders. In the case of resisting neoliberal capitalism by promoting co-ops, those who are associated with neoliberal capitalism are possibly excluded from the collective 'we' of the cooperative movement, which can work as an engine for the accumulation of negative affect in relation to capitalism and its associated subjects.

When it comes to critical resistance, it is important to acknowledge the affective dimension. If affect is being circulated in the same way as how the dominating discourse moves signs, it indicates that the domination might be reproduced. Since subjects are in a way already produced as free in neoliberal discourse (Hamann 2009), it also implies an autonomy regarding affect. Affect circulating between subjects through their participation in a neoliberal capitalism system (Reber 2012) enables individuals to act emphatically but at a distance, without forming collectives. This implies that critical resistance to neoliberal capitalism that escapes the production of neoliberal subjects regarding affect ought to articulate adherence to a specific collective rather than affect through individual autonomy. By taking the discursive, circulatingaccumulating aspects of affect into account in the analysis of the potential resistance in the present marketing campaign, it can further the understanding of the challenges faced by the discursive performance of critical resistance to neoliberal capitalism (D’Aoust 2014).

\section{Analysis: campaigning for cooperatives}

This article examines if and how an emancipatory, critical resistance (Hoy 2004) to the domination of neoliberal capitalism is being discursively performed in a global marketing campaign, 'Building a better world now' (ICA 2016a), aimed at spreading the cooperative identity. The analysis recreates the discursive structure of the campaign, thematised into three 
parts of how resistance to neoliberal capitalism is mainly being performed; i.e., through articulations (1) of co-ops as a loving 'we', (2) of co-ops as better than 'conventional corporations', and (3) of the goal to achieve economic growth. The final discussion concludes that the performed resistance of the campaign does not entail critical resistance.

\section{Cooperatives as a loving 'we'}

The sign 'cooperative' is the most recurrent one in the campaign's marketing material and emerges as an important key signifier. It might function as a nodal point, but comes forth as the sign that needs to be filled with meaning. Co-ops are, for instance, explicitly associated with long lists of adjectives in the fourth (4) PowerPoint presentation, which forms a description about what co-ops are. Several slides begin with the headline 'Who we are' and ends with 'We are a cooperative', and the content in between consists of descriptive articulations, such as the following:

\footnotetext{
We are family.

We offer value.

We are people helping people.
}

The meaning of co-ops is articulated through similarities between the sign 'cooperative' and the positively displayed adjectives. Similar articulations are produced in other parts of the campaign. In the second PowerPoint presentation (2), several slides show an image of clusters of words in different size, where the largest, centred sign 'cooperate' is surrounded by signs such as 'vision', 'community', 'help' and 'together'.

These examples reflect a general pattern in the campaign discourse - the representation of positive affect concerning the sign 'co-operative'. The continuous sticking together of the sign 'co-operative' with positive adjectives, such as 'value', create the impression of co-ops as positively valuable, which may - if circulated through repetition - contribute to the accumulation of positive affect in relation to co-ops as a representation (Ahmed 2004a). In this way, resistance is performed by representing an alternative to neoliberal capitalism as positive and attempting the circulation of loving affect regarding the figuration.

Furthermore, articulations of positive assemblies of people through signs such as 'family', 'together', and 'everybody' are being connected to co-ops in the examples. If such a narrative is circulated, it can generate the effect that a group, a 'we', is being formed. The wording 'We are people helping people' depicts the members of the 'we' as caring for others, which articulates the collective as a loving one. According to Ahmed (2004b), feelings can 
become generated by narratives, which in this case can accumulate feelings of collectiveness among the people who are appealed by the articulated 'we'. It may bring them closer to each other and be interpreted as an affective appeal to love between the group members, and since the formation of a 'we' differentiates that collective from 'them' who are excluded, it may accumulate distant affect or potentially hate in relation to 'them' (Ahmed 2004b). This indicates that affect is involved in the performed resistance of the campaign through the representation of a positive collective, which might, on the one hand, motivate members of co-ops to feel stronger for each other and enhance their wish to promote the movement and circulate positive affect in relation to it, while on the other hand, it might motivate non-members' to join the movement - i.e., if they do not feel excluded and further distanced by the strong articulation of a 'we'.

The representations of togetherness can further entail resistance through a shift in the reproduction of subjects (Butler 1993). The campaign discourse represents the 'we' as consisting of subjects that aid and support each other, acting collectively, and driven by social, emphatic values in a way that challenges the neoliberal discourse of autonomous and selfinterested subjects. The narrative of caring affect can thus be understood as the production of a different kind of subjectification (Foucault 1982), however, it cannot be understood as critical resistance through desubjectification since the shift only entails some aspects. The cooperative subject is still produced as an entrepreneur that strive for business, although collectively and with social aims (see Holborow 2015 on social entrepreneurship). The following quotes from different parts in the fourth (4) presentation exemplifies how this is being articulated in the campaign:

Cooperatives working together and supporting other cooperatives creates more business.

Together we are strong!

The two quotes articulate that togetherness can contribute to aspects that are outlined as beneficial for co-ops (support, more business, strength). The non-co-operators are articulated as a threat that the cooperative movement can fight together, as indicated by the use of the sign 'strong'. The articulations of co-ops as a loving and caring collective that feels for others is here combined with economic-rational arguments of how to create business, which reproduces dominant values of a neoliberal capitalist discourse. This point to the conclusion that resistance, but a non-critical one, is being performed throughout the campaign. The centrality of 
entrepreneurship and economic business is present in the campaign discourse in several ways as shown in the next section.

\section{Cooperatives in relation to conventional corporations}

In the campaign discourse, the sign 'cooperative' is predominantly differentiated from 'conventional corporations' - the most common articulation of difference in the material. In the first (1) PowerPoint presentation are the signs 'corporation' and 'cooperative' differentiated in a comparative chart that lists what corporations and co-ops count in their internal economics, such as quarterly returns vis-à-vis sustainable returns. The meaning of the sign 'cooperative' is continuously being explained in relation to corporations, not the other way around, which is exemplified by the above-mentioned listing of descriptive adjectives concerning co-ops. One example from the third (3) PowerPoint presentation shows this relationship:

Once a consumer understands a cooperative they are $78 \%$ more likely to choose a cooperative business over a conventional business.

The quote indicates that consumers in general are knowledgeable about conventional businesses, often articulated as corporations in the campaign. The association of corporations with the sign 'conventional' suggests that its meaning does not need further explanations. This makes 'corporation' function as a nodal point in the campaign discourse, and signs such as 'cooperative' receive meaning in relation to this nodal point. The centrality of 'conventional corporations' implies that the campaign discourse is affected by and possibly reproducing neoliberal capitalism. Lack of knowledge about cooperation is simultaneously articulated as the main obstacle for the cooperative movement and presented as an explanation for why co-ops are not more prevalent. Although the campaign states that co-ops are widely spread in America (presentation one (1)), the prevalence is significantly lower when compared with corporations. The following examples from two slides in the first (1) presentation show how the articulated explanation also constructs co-ops as better than conventional corporations:

When we asked people about cooperatives, we were surprised to find out how little they knew.

More awareness increases the amount of customers choosing cooperatives.

Knowledge about cooperation is presented as low, and 'more awareness' is articulated as positive for the cooperative movement. The articulation insinuates that co-ops are better - if 
people understand how co-ops work, they are obviously positive about them. The low prevalence that might function as an argument against co-ops - why are they not more common if they are so good? - is discursively turned into an argument in favour of co-ops. Lack of knowledge is articulated as a problem that increased knowledge can solve, which legitimises the activity of the marketing campaign.

The nodal point 'corporation' is rarely associated with other descriptive signs in the collected material, but there are some articulations of similarity that produce a certain understanding of the sign; for example, the attachments to the signs 'stock value' and 'profit' in the comparative chart in the first (1) presentation, mentioned above. The meaning of 'conventional corporation' is also produced as equal to the present global economy, which is exemplified by a line in the first (1) PowerPoint presentation:

The world we live in is dominated by the conventional corporation.

By articulating corporations as dominant in the world, the sign 'world' relates to the same meanings as 'corporation'. The current position of the world is in turn associated with economic inequality, which a text in the first (1) presentation exemplifies:

$1 \%$ of the world's population holds over $50 \%$ of its wealth.

The world, and therefore also 'conventional corporations', is associated with statistics of global inequality. Corporations are articulated as causing economic inequalities in the world, and inequalities are produced as an effect of the dominance of conventional corporations. Since coops are differentiated from 'corporations', these articulations shape the meaning of both - coops are indirectly represented as offering the solution of equality. This is further strengthened by the association of co-ops with comparative adjectives such as 'better' and 'superior' throughout the campaign. One example is the name of the whole campaign, 'Building a better world now', which articulates the direction of the difference: co-ops are better than corporations. This indicates that resistance is performed through the identification of a problem, global inequalities, and the articulation of an idealised utopia of global equality. Co-ops and cooperative subjects are articulated as those that can create equality and the campaign discourse thereby articulates what kind of social change that is called for. Those who speak against cooperation are indirectly constituted as speaking in favour of inequality and individual, monetary greed, in contrast to empathy and care represented as cooperative ideals. There is no 
mention of the 'emotionality' of capitalist discourse and the justifying notion of being most beneficial for all (Reber 2012). The articulation of corporations and the global capitalist economy as undesirable can be understood as an attempt to 'stick' negative affect to 'corporations' and 'capitalism', which if repeated might accumulate feelings of hate to those representations (Ahmed 2004a).

Another example of the relationship between co-ops and corporations are the headlines in a set of slides in the first (1) PowerPoint presentation:

What if the world's largest corporations were cooperatives?

Understanding our current position is imperative in charting our future.

The headlines suggest a rethinking of the presently dominant economy towards a cooperative one. The content below consists of calculations of how much income the employees in global organisations like Apple and Walmart would receive if they were co-ops, in an attempt to reformulate what to do with the profits. The cooperative alternative is promoted by advocating distribution among the employees, instead of capital accumulation for more or less external owners. The resistance activity is thereby partly performed through criticism of the economic actions (profit distribution and private ownership) of corporate organisations, and the cooperative model is promoted as an alternative way to act. The campaign thus produces both economic-rational and affective arguments as resistance to neoliberal capitalism. The campaign discourse produces subjects not only as emphatic and supportive, but also as economic calculators that adhere to arguments of (economic) benefits that are accountable according to neoliberal capitalism - the employees would take part of the profit and potentially earn more money if the above mentioned global organisations were co-ops. This points to a reproduction of the neoliberal, capitalist discourse within the marketing campaign. The same notion concerns the continuous presentation of 'cooperative' as a 'business model' which articulates doing business as a way of organising action that holds for both co-ops and corporations. Neoliberal, capitalist discourse is not challenged in this respect; business and entrepreneurship is reproduced as central values.

In the articulated differentiation between corporations and co-ops, co-ops are associated with other values in some ways, but signs such as profit, income and business - commensurable with neoliberal capitalism - are being associated with both corporations and co-ops. The performed resistance of the campaign is thereby accountable in a neoliberal discourse even if the primary goal of capital accumulation is circumvented, which indicates that the performed 
resistance is not critical (Hoy 2004). The campaign discourse cannot be understood as emancipatory resistance to the domination of neoliberal capitalism since its logic is simultaneously being reproduced to some extent. The following section further points to this conclusion through the analysis of how the promoted change is being articulated in the campaign discourse.

\section{Cooperatives aiming for economic growth}

The sign 'building', included in the campaign name 'Building a better world now', is one of the most frequent signs in the campaign discourse since the campaign title occurs in several PowerPoint slides. In slides where it is not used, other signs that refer to some form of transformative movement are prevalent, such as 'create', 'action', 'change', 'engage', 'increase', 'growth', etc. One example is the text from a slide in the first (1) presentation:

Our Vision of 2020: Create a Movement.

Our unified vision compels us to move forward and shift momentum.

The sign 'create' is here combined with 'move forward', which articulates the aim of the campaign - change from the present condition to something prospectively different. Signs of action and change are throughout the campaign associated with descriptions of motives and possible impacts; here the 'vision' is articulated as a sought future (a movement in 2020) that 'compels us' to act toward that vision. In other examples the present condition is outlined as a reason for action; for instance, the above-mentioned articulation of undesirable world inequality as caused by capitalism. The signs 'growth' and 'increase', frequently occurring in the campaign discourse, are associated with both economic increase and the number of cooperative businesses and people engaged in co-ops, and shapes the kind of change that is called for. One example from the second (2) PowerPoint presentation shows how 'growth' is associated with organisational size and economic success:

The cooperatives that exist today are already making a big impact on their communities. Helping these cooperatives grow and become more successful can shift the momentum of the world economy.

The sign 'growth' here is associated with existing co-ops and more success. Growth is thereby articulated as something positive, as a legitimate goal of the campaign and a means to achieving 
social change. The following wording from the second (2) presentation exemplifies the positive articulations of 'growth' and 'increase':

Everybody Wins: Increased Exposure \& Growth Benefits all Cooperatives.

As our movement gains visibility and consumer understanding the potential for new cooperatives and larger existing cooperatives increases.

Positive words like 'wins' and 'benefits' are used together with 'growth' and 'increase', filling the latter signs as desirable. This coincides with neoliberal discourse, where the repeated use of words such as 'growth', 'wealth', and 'output' reinforces the way in which well-being for societies and individuals is being conceived, i.e., through economic market exchange (Holborow 2015, Massey 2013). Similarly, the neoliberal construction 'social entrepreneurship', that places social projects within the entrepreneurial idea, is resting on 'confidence in the ability of existing institutions and business mind-sets to actually deliver inclusiveness and empowerment' (Holborow 2015, p. 84). The articulations of action and change in the present campaign discourse are for example paralleled in the slogan of a recent neoliberal project of social entrepreneurship in Ireland: 'Think Big, Act Now, Change Ireland' (Holborow 2015, p. 80).

In the present campaign, the idealised (social) change and the aim of the resistance activity is articulated as a growing cooperative movement and enhanced cooperative sector in the economic sphere. It is implied in the example above that growth should be sought for by 'everybody'. The formulation 'everybody wins' refers to all cooperative organisations, but the meaning can be extended to involve all people engaged in co-ops as well as those without previous engagement. To join the cooperative movement is articulated as an emphatic, loving alternative that is beneficial in both an affective and rational-economic sense. The articulation 'beneficial for everyone' is paralleled in the legitimation of neoliberal capitalism (Illouz 2007, Reber 2012). No one is by definition excluded from the open, free market (but no specific subject is included either), but regarding cooperation, the enjoyment of benefits requires membership in co-ops. The 'everyone' is thus more restrictive in the campaign than in freemarket legitimisations of neoliberal capitalism, and affect is being circulated through adherence to a specific collective, thus challenging the articulation of affect through individual autonomy in neoliberal capitalism. Whether the cooperative economy is aimed to encompass everyone in the global economy is not explicated in the campaign, but the campaign's call for growth indicates that more people are invited to join the movement. 
The sought growth that is outlined in an economic sense is paralleled with the centrality of income throughout the campaign discourse. One example from a set of slides in the first (1) PowerPoint presentation that shows the widespread unawareness of co-ops presents income range as the only descriptor of personal identity:

'I have never heard of a co-operative before.'

- Income $\$ 26,000$ - $\$ 50,000$

The example indicates that money is a central value in the campaign discourse. Earning income is articulated as an important value, which is also reflected in the above-mentioned slides where corporations were rewritten as co-ops regarding profit distribution. Equality and democracy are thus connected to economic democracy and equality - articulations of inequality in ownership, income, and wealth are being related to the problematic, present global economy. Co-ops are articulated as a solution to economic injustices, which means that the value of money is explicated not only in the problem but also in the solution. This indicates that the marketing campaign reproduces a capitalist, neoliberal discourse where money is a privileged value that rational individuals consider when deciding how to act. However, a solitary goal of capitalist profit accumulation is challenged by the promotion of social benefits in the cooperative alternative. The emphasis on social values entails resistance, as the analysis above has shown, but the discourse in the collected material simultaneously reproduces neoliberal logic which stifles the critical, emancipatory effect.

\section{Concluding discussion: campaigning for cooperatives as non-critical resistance}

A neoliberal capitalism with discourses of rationality, entrepreneurship and autonomy that produces individuals as free Homo Economicus is challenging for the prospect of resistance and has persisted to dominate global economy in spite of the critique directed against it (Boltanski and Chiapello 1999/2007, Hamann 2009). For the cooperative movement to perform effective resistance to neoliberal capitalism, it has to resist rather than reinforce the productive power of the neoliberal, capitalist discourse itself (Foucault 1977, Hoy 2004). The present analysis of the marketing campaign 'Building a better world now' (ICA 2016a) shows that resistance to the domination of neoliberal capitalism is being performed in some respects through articulations of co-ops a loving 'we', through comparison with conventional corporations, and by the articulated aim for (economic) growth - but neoliberal, capitalist discourse is simultaneously being reproduced. This section discusses the conclusion that the 
resistance activity of the campaign discourse is not to be understood as critical resistance in the way that is conceptualised by Hoy (2004); i.e., as emancipatory resistance to domination that resists being co-opted by the power of domination.

The campaign discourse performs resistance to neoliberal capitalism through a continuous sticking together of the sign 'cooperative' with positive adjectives, which may - if circulated through repetition - contribute to the accumulation of positive affect in relation to the representation of co-ops (Ahmed 2004a), and is combined with articulations that may generate negative affect regarding 'conventional corporations' by representing them as the cause of global inequalities. Articulations of the cooperative movement as a supportive collective that emphasises social values entail a narrative that may appeal to certain subjects and generate effects by sticking them closer to each other and further circulate positive affect. Such an accumulation of affect might resist neoliberal capitalism by empowering an alternative to its dominance, but it does not necessarily entail critical resistance (Hoy 2004). Although the campaign discourse produces a somewhat different subjectification (Foucault 1982), from the individual autonomy of self-interested Homo Economicus (Hamann 2009, Brown 2015) to the collective autonomy of supporting, caring co-operators, the idea of rational entrepreneurs that seek individual (economic) gain is being reproduced. Despite the collective member benefits can each co-operator ask, what's in it for me? The answer is outlined as participation in a loving community as well as monetary benefits - social and economic ideals are emphasised and coops offer both. The utilitarian argument of neoliberal capitalism as emphatic and most beneficial for most people (Boltanski and Chiapello 1999/2007, Illouz 2007, Reber 2012) is met with a similar narrative in the campaign discourse that promotes cooperation - it is not critically different.

Hoy (2004) outlines that critical resistance should entail emancipation from the power of productive discourses without being co-opted by the power of domination. The cooperative movement has the potential to strive for emancipation from neoliberal capitalism (Satgar 2007, Pahnke 2015); however, the cooperative alternative is described as a business model and economic values of profit and growth are continuously emphasised, which are aspects that are commensurable with neoliberal capitalism (Boltanski and Chiapello 1999/2007, Holborow 2015). Co-ops are articulated as another way of performing business and distributing profit through emphasis on equality and care for others, but the outlining of economic values as privileged does not significantly deviate from the sense-making of neoliberal capitalism. This indicates that the resistance activity in the campaign is co-opted by the power of dominating economic discourse and must therefore be understood as an uncritical form of resistance. The 
article's initial quote 'Capitalism with a conscience', from the campaign website (buildingabetterworldnow.coop, (ICA 2016a)) is a direct example of this. The sign 'capitalism' is articulated as compatible with a cooperative economy and the performed resistance does not explicitly deviate from a capitalist agenda. It is possible that the use of the word 'capitalism' together with the sign 'conscience' here could be understood as resistance through 'reverse discourse', by filling the sign with a different meaning (Hoy 2004), but since a neoliberal, capitalist discourse is present in the campaign - for example, by reproducing the value of economic gain - it is more probable that the quote reflects a normalisation of the dominant power of capitalism.

The resistance to neoliberal capitalism through the campaign discourse precludes certain assumptions about the social reality. This can be understood as an example of the circumstance where resistance is related to social constraints that are understood in the structure that produces these constraints, and is therefore only meaningful in contexts where these constraints are practised (Hoy 2004, p. 2). The articulated resistance is concerned with work, income, entrepreneurship and business, aspects that are central for the characteristics of neoliberal capitalism as well. The campaign discourse concerns a change in performing business, and offers affective and economic arguments for why cooperation is a 'better' alternative. The campaign calls for collective, entrepreneurial business that aims for member benefits and social values on cooperative markets as resistance to neoliberal capitalism, associated with autonomous performances of entrepreneurial business that aims for profit accumulation on competitive markets produces. The social reality is assumed to be an economic one. The economic sphere is articulated as a societal context in which the pursuit for social ideals can be conducted (see Holborow 2015 on social entrepreneurship), indicating a continuous subjectification in the shape of Homo Economicus (Brown 2015, Peters 2016). Whether the resistance to neoliberal capitalism is most effectively performed in the same context of domination is a possible case for future research - the present article indicates that critical resistance to the productive power of neoliberal, capitalist discourse is challenging.

It might be a resistance strategy to follow the logic of the dominant discourse in order to make the performance explicable according to its rules and values, but such a move should, in the present case, not be conceptualised as critical resistance. This campaign is not a politics of deviance (Cohen 2004), not a sidestepping of the dominant values of the discourse - rather, it is a way to construct co-ops as not so deviant after all, in accordance with Whyman's (2012) attempt to include co-ops in mainstream economic history. Instead of critical resistance to neoliberalism, for example by co-opting domination's own strategy to resist emancipatory 
efforts (Hoy 2004), this particular campaign reproduces, normalises and neutralises its logic and social practices. Since the core value of profit accumulation is challenged, discursive articulations of cooperation offer some potential for critical resistance, on condition that it manages to resist adaptation to neoliberal logic (Satgar 2007). The challenge for the performance of resistance to neoliberal capitalism is how the latter dominates not only the practices of organisations, but also how subjects are being disciplinarily produced as already free to act. Neoliberal logic transcends economic capitalism and there is a constant risk of reproducing it, which indicates that critical resistance to its domination should take several levels into account in order to be emancipatory enough. To conclude, resistance is being performed through the campaign discourse, but it is an uncritical one.

This article shows, in line with previous research (e.g. Satgar 2007, Pahnke 2015), that co-ops offer a potential to perform resistance to neoliberal capitalism, but adds insight to the difficulties faced by the performance of a critical resistance that does not simultaneously reproduce the power of dominant discourse (Hoy 2004). This article strengthens the understanding that co-ops are, to a large extent, constructed in comparison with and through criticism of other business models (Puusa et al. 2013), and that affect and economic-rational reasoning are intertwined in economic discourses (Illouz 2007, Reber 2012). Previous research on cooperation as resistance is, however, scarce, and further research could shed light on the challenges and possibilities of resisting the values of neoliberal capitalism. The study presented in this article is not an exhaustive account of the discursive construction of co-ops as resistance, or of the cooperative movement's social practice of resistance to the domination of neoliberal capitalism. Rather, it is an argument for the potential of performing such resistance, and an acknowledgement of the challenges faced by emancipatory resistance to domination. Furthermore, the article shows how discursive articulations of affect can be a central element in the performance of resistance, and how resistance can be useful in understanding the intertwining of social and economic ideals in discourses. More research on this subject is hereby called for. Resistance Studies is a growing academic field and the possible contributions of turning the scientific gaze towards cooperation and neoliberal capitalism is manifested with this article. 


\section{Disclosure statement}

No potential conflict of interest was reported by the author.

\section{Notes on contributor}

Kristin Wiksell is affiliated to the Centre for Regional Studies at Karlstad University. Her research primarily concerns organisation, power and resistance from a sociological perspective, with a specific focus on how worker cooperatives in Sweden are being constructed in social interaction between the employees.

\section{ORCID}

Kristin Wiksell http://orcid.org/0000-0002-7641-2744

\section{References}

Ahmed, S., 2004a. Affective economies. Social Text 79, 22 (2), 117-139.

Ahmed, S., 2004b. Collective feelings. Theory, Culture \& Society, 21 (2), 25-42.

Ahmed, S., 2014. The cultural politics of emotion. Edinburgh: Edinburgh University Press.

Bayat, A., 2000. From 'dangerous classes' to 'quiet rebels': Politics of the urban subaltern in the Global South. International Sociology, 15 (3), 533-557.

Boltanski, L. and Chiapello, E., 1999/2007. The new spirit of capitalism. London: Verso.

Brown, W., 2015. Undoing the demos: Neoliberalism's stealth revolution. New York: Zone Books.

Butler, J., 1988. Performative acts and gender constitution: An essay in phenomenology and feminist theory. Theatre Journal, 40 (4), 519-531.

Butler, J., 1993. Bodies that matter: On the discursive limits of 'sex'. New York and London: Routledge.

Butler, J., 2015. Notes toward a performative theory of assembly. Cambridge and Massachusetts: Harvard University Press.

Cacho, L.M., 2012. Social death: Racialized rightlessness and the criminalization of the unprotected. New York: NYU Press.

Clough, P.T. and Halley, J., 2007. The affective turn: Theorizing the social. Durham, NC: Duke University Press.

Cohen, C.J., 2004. Deviance as resistance: A new research agenda for the study of black politics. Du Bois Review, 1 (1), 27-45.

Cooperatives for a better world, 2017. Cooperatives for a better world. Cooperatives for a better world. Available from: https://cooperativesforabetterworld.coop/ [Accessed 10 February 2017]. 
D'Aoust, A., 2014. Ties that bind? Engaging emotions, governmentality and neoliberalism: Introduction to the special issue. Global Society, 28 (3), 267-276.

Evans, W.T., 2007. Counter-hegemony at work: Resistance, contradiction and emergent culture inside a worker-occupied hotel. Berkeley Journal of Sociology, 51 (globalization \& social change), 33-68.

Foucault, M., 1977. Discipline and punish: The birth of the prison. London: Penguin Books.

Foucault, M., 1980. Power/knowledge. Brighton: Harvester Press.

Foucault, M., 1982. The subject and power. In: Dreyfus, H. L., Rabinow, P. and Foucault, M., eds. Beyond structuralism and hermeneutics. Chicago: University of Chicago, 208-226.

Foucault, M., 1988. The history of sexuality, Volume 1: Introduction. New York: Vintage.

Foucault, M., 1997. Ethics: Subjectivity and truth. New York: New Press.

Foucault, M., 2008. The birth of biopolitics: Lectures at the Collège de France, 1978-1979. New York: Palgrave Macmillan.

Glass, M.R. and Rose-Redwood, R., 2014. Performativity, politics, and the production of social space. New York: Routledge.

Hamann, T.H., 2009. Neoliberalism, governmentality, and ethics. Foucault Studies, 6, 37-59.

Haugaard, M., 2012. Rethinking the four dimensions of power. Journal of Political Power, 5 (1), 35-54.

Harvey, D., 2005. A brief history of neoliberalism. Oxford: Oxford University Press.

Holborow, M., 2015. Language and neoliberalism. New York: Routledge.

Hollander, J.A. and Einwohner, R.L., 2004. Conceptualizing resistance. Sociological forum, 19 (4), 533-554.

Hoy, D.C., 2004. Critical resistance: From poststructuralism to post-critique. Cambridge, MA: MIT Press.

ICA, 2016a. Building a better world now. Cooperatives for a better world. Available from: http://buildingabetterworldnow.coop/ [Accessed 10 June 2016].

ICA, 2016b. International Co-operative Alliance. International Co-operative Alliance. Available from: http://ica.coop/ [Accessed 10 June 2016].

ICA, 2016c. What is a co-operative? International Co-operative Alliance. Available from: http://ica.coop/en/what-co-operative/ [Accessed 10 June 2016].

Illouz, E., 2007. Cold intimacies: The making of emotional capitalism. Cambridge: Polity Press. Laclau, E. and Mouffe, C., 2008. Hegemonin: Den socialistiska strategin. Göteborg and Stockholm: Glänta/Vertigo. 
Lilja, M. and Vinthagen, S., 2014. Sovereign power, disciplinary power and biopower: Resisting what power with what resistance? Journal of Political Power, 7 (1), 107-126.

Marx, K., 1867/2013. Capital: A critical analysis of capitalist production. Ware: Wordsworth Editions.

Massey, D., 2013. Vocabularies of the economy. Soundings, 54, 9-22.

McElhinny, B., 2010. The audacity of affect: Gender, race, and history in linguistic accounts of legitimacy and belonging. Annual Review of Anthropology, 39 (1), 309-328.

Nietzsche, F., 1959. The portable Nietzsche. London: Penguin.

Odysseous, L., Death, C. and Malmvig, H., 2016. Interrogating Michel Foucault's counterconduct: Theorising the subjects and practices of resistance in global politics. Global Society, 30 (2), 151-156.

Pahnke, A., 2015. Institutionalizing economies of opposition: Explaining and evaluating the success of the MST's cooperatives and agroecological repeasantization. Journal of Peasant Studies, 42 (6), 1087-1107.

Paulsen, R., 2010. Arbetssamhället: Hur arbetet överlevde teknologin. Malmö: Gleerups.

Peters, M.A., 2016. Education, neoliberalism, and human capital: Homo economicus as 'entrepreneur of himself'. In: Springer, S., Birch, K. and MacLeavy, J., eds. The handbook of neoliberalism. New York: Routledge, 297-307.

Puusa, A., Mönkkönen, K. and Varis, A., 2013. Mission lost? Dilemmatic dual nature of cooperatives. Journal of Co-operative Organization and Management, 1 (1), 6-14.

Reber, D., 2012. Headless capitalism: Affect as free-market episteme. Differences, 23 (1), 62100.

Richard, A. and Rudnyckyj, D., 2009. Economies of affect. The Journal of the Royal Anthropological Institute, 15 (1), 57-77.

Rothschild, J. and Whitt, J.A., 1986. The cooperative workplace: Potentials and dilemmas of organizational democracy and participation. Cambridge: Cambridge University Press.

Satgar, V., 2007. Cooperative development and labour solidarity: A neo-Gramscian perspective on the global struggle against neoliberalization. LABOUR, Capital and Society, $40(1 / 2)$, $56-79$.

Scott, J.C., 1985. Weapons of the weak: Everyday forms of peasant resistance. New Haven, CT: Yale University Press.

Sointu, E., 2016. Discourse, affect and affliction. The Sociological Review, 64 (2), 312-328.

Spear, R., 2004. Governance in democratic member-based organisations. Annals of Public and Cooperative Economics, 75 (1), 33-59. 
Springer, S., 2010. Neoliberal discursive formations: On the contours of subjectivation, good governance, and symbolic violence in posttransitional Cambodia. Environment and Planning D: Society and Space, 28, 931-950.

Springer, S., 2016a. Fuck neoliberalism. ACME: And International Journal for Critical Geographies, 15 (2), 285-292.

Springer, S., 2016b. The discourse of neoliberalism: An anatomy of a powerful idea. London: Rowman and Littlefield International.

Sørensen, M.J., 2016. Constructive resistance: Conceptualising and mapping the terrain. Journal of Resistance Studies, 2 (1), 49-78.

Torfing, J., 1999. New theories of discourse: Laclau, Mouffe and Žižek. Oxford: Blackwell.

Türken, S., et al. 2016. Making sense of neoliberal subjectivity: A discourse analysis of media language on self-development. Globalizations, 13 (1), 32-46.

Varman, R. and Chakrabarti, M., 2004. Contradictions of democracy in a workers' cooperative. Organization Studies, 25 (2), 183-208.

Weber, M., 1927/2007. General economic history. New York: Cosmo Classics.

White, R.J. and Williams, C.C., 2012. The pervasive nature of heterodox economic spaces at a time of neoliberal crisis: Towards a 'postneoliberal'” anarchist future. Antipode, 44 (5), $1625-1644$.

White, R.J. and Williams, C.C., 2016. Everyday contestations to neoliberalism: Valuing and harnessing alternative work practices in a neoliberal society. In: Springer, S., Birch, K. and MacLeavy, J., eds. The handbook of neoliberalism. New York: Routledge, 603612.

Whyman, P.B., 2012. Co-operative principles and the evolution of the 'dismal science': The historical interaction between co-operative and mainstream economics. Business History, 54 (6), 833-854.

Winther Jørgensen, M. and Phillips, L., 2000. Diskursanalys som teori och metod. Lund: Studentlitteratur.

\footnotetext{
i The quote, retrieved in June 2016, comes from a headline on the website buildingabetterworldnow.coop (ICA 2016a), now cooperativesforabetterworld.coop, managed by Cooperatives for a better world (2017), initiated by the International Co-operative Alliance in 2015.

ii The campaign has grown since the analysed materials were collected. It does presently (January 2017) consist of an extensive website with marketing materials such as videos and statistics, accessible from the internet domain cooperativesforabetterworld.coop (Cooperatives for a better world 2017), previously buildingabetterworldnow.coop (ICA 2016a).
} 